1074

(30) $M I=\alpha v h^{3}\left(\frac{16 y}{\pi h} \sum_{1,3,5}^{n} \ldots \frac{1}{n^{3} c}-\frac{32}{\pi^{4}} \sum_{1,3,5 \ldots}^{n} \frac{1}{n^{4} c} \sin \frac{n \pi y}{2 h}\right)$ $\cdots(31)_{0}$

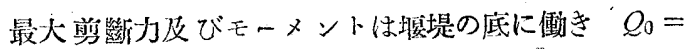
${ }_{\pi^{3}}^{16} \alpha z h^{2} \sum_{1,3,5 \cdots}^{n} \frac{1}{n^{3} c} \cdots(32) \quad M_{0}=\alpha w h^{3}\left(\frac{16}{\pi^{3}} \sum_{1,3,5 \cdot: \cdot}^{n} \frac{1}{n^{3} c}-\frac{32}{\pi^{4}}\right.$

21. 紡

\section{【175】グレッドヒル式複式杼無 し自動織機}

[Gledhill Weaving Co. Ltd. Tex. Manuf., 1932-5-

頁 184-186] 自動織機の案出は換杼式にしろ換管式に しろ總べて飛标を用ふことを基礎として考へられたので あるが緯絲を經絲の間に插入する方法としては必ずしも 杆を用ひなくてもよい。緯絲引这久桿を闭ひてをよい理 由で㐫る。從つて緯絲ら菦み桿さ基礎とした自動織機 も可能でなければならない。元來織機の艮否は璉動力゙如 何なる程度に自動的で女るか、運動が確實に行はれる か、取报ひか簡單であるかと云ら事は勿論經緯絲切斷度 數、出來上り品の品質、樰物出來高等に依つて決定しな ければならない。グレッドとル式織機に於ては标を用 びず緯絲引込み桿を用ひ緯絲を自動補紗 し得るや5にし たので幾種類の緯絲でも自由に且つ容易に挿入し而子自 動織機の作用を行ふ。之に反し普通の自動織機では一種

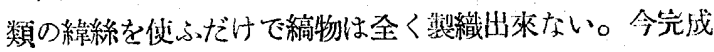
されてるるのは梳紡毛絲製織为のものであるが木綿及 絹織朋としての織機製作も亦自ら可能である。以下圆に 示したものは筬幅 90 师のハッチンソン社のドブクロス 織機に自動裝置を裝僃したるのでもる。緯絲の插入は普 通の杍無し機と同栐で一方の插入桿で緯絲の端を中央に 連び之と同時に反對側から淮入した引込々棉の端に之 を喰へさせ此の棹の後退に佉つて 緯絲を織物幅總體に 雨入し終尔るので㟧る。筬打は普通織機そ全然變らな い。緯絲は大形の圓錐挍とされ緯絲棚の上に並列され漏 斗形の案內金の上部の日から引き出される。緯絲は2列 に並べられ一つの圓錐撩の終端は次の列の圓錐撩の先端 に結ばれてるるから緯絲は時々補給のため見超はるだけ

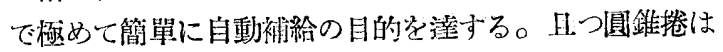
緯管港の 10 數倍の絲量を在するから補給の手數は非常 に少ない。第 1 圖には緯絲は 7 禋類の子のを示 したが普通此の 程陵の緯絲で間 に合らから之を 限度とした。各 の緯絲の閉には 分㒕板があつて 絲のバルーニン

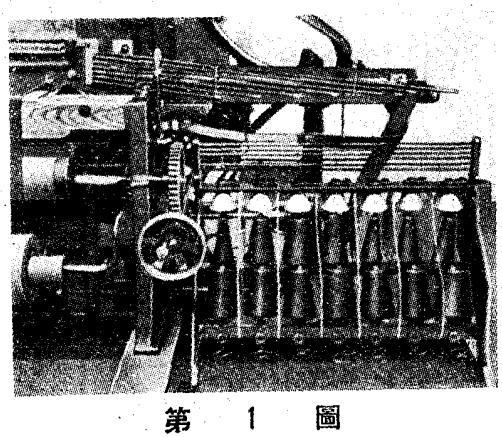

绿 $\left.\sum_{1,3,5 \cdots}^{n}(-1)^{\frac{n-1}{2}}\right)$

(33) 之に $T=1 \frac{1}{3} \sec , \alpha=0 \cdot 1, h=$ $800 \mathrm{ft}$ 等の數値を入れると $Q_{0}=1,253$ ton $/ \mathrm{Et} \quad M_{0}=$ $397,600 \mathrm{ft}-t o n / \mathrm{ft}$ となる。

(板行)

織

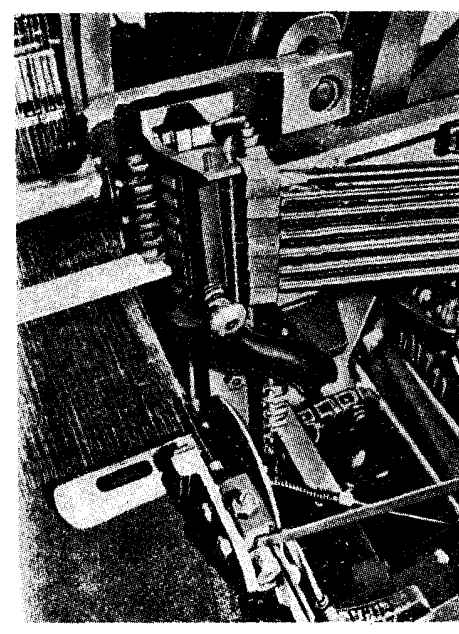

第 2 圆

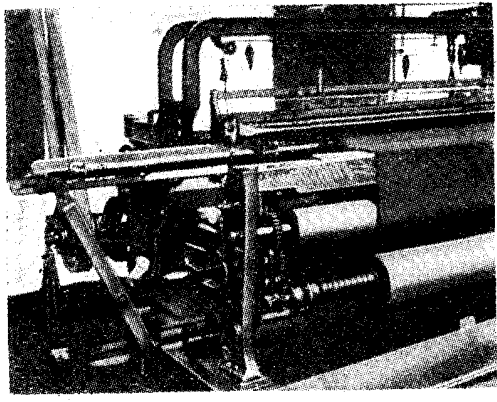

第 3 圖
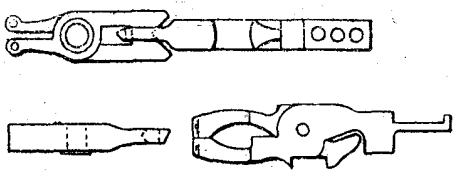

第 4 圖

グを防いでるる。 案內目から引き出 された絲は加張裝 置を通過し筬框に 装置した割管を通 り䉝耳近くに於を 7 筒 7 段に厥を作 つて居る緯絲挏器 に導加(第 2 圖) ドビー器を利用し 所要の緯絲を隨時 插入の位犆に持ち 來すことが出來 る。㨂入棉は此の 㨔器艾其の尖端で

經絲開口山に 抑し淮めるが この䄸はアル ミニゥム製で 極めて輕く滑 動部分は球面 承けとなり縻 擦を輕减する やらに出來て るるから運動 は圓滑輕快で める。此の棹 は縱に裝置し た緯打ち桿の 上端に連絡し この緯打桿の動摇に估つて左石動を行ふ。(第3 圆) 此の 装置に依ると緯絲拆入は全然積極的に行はれるのみなら ず運動が輕快でもるから标を优ふ：織機の樣に始動の位置 を選ぶ必要がなく何處の位置から始めで如何なる低 速でも緯絲插入に失敗する樣なことはない。唒样打ち の急激な作用が除かれるので所要馬力は非常に減少す

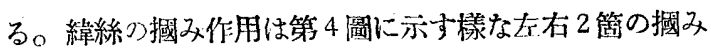

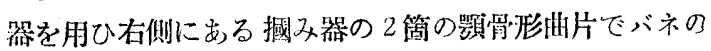

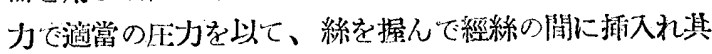
の先端に $1 / 8^{\prime \prime}$ 位絲の端を出してをく。左側摁久器は右

[筝 35 榮第 186 號 


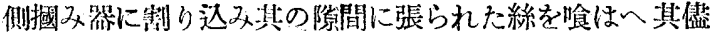
後退して絲の插入を笔了する。此の時右側掝器は日を閶

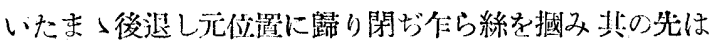

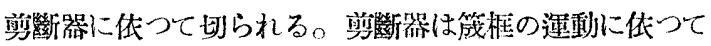
迥はされる圆板で耳に接近して装備して山る。布の兩端 から食み出る緯絲は特殊耳織器に泝り絲の端を耳組織中 に押し入れられ俿暏のやらな組織を形成する。此の器は 莫大小機の針先に似大瀻䋉な針先の作用を行ひ其の目的 を洼する。兩侧の拆入桿のた女織機の幅は 16 以に澾す る。同轉は每分 80 90 整織能率は 97\%1 職工 6 台持 ち緯絲は强力の弱いものでも切斷の徳はない。(安東)

【176】輪具精紡機の高度伸率試驗〔Henry Meynel Ltd., Tex. Manuf., 1932-5, 頁 188] 此の試 驗はチェコスロバキヤ、オネスタット市ウィリヤムブラ ス社に於て行つたもので、既工場には Meynel W.T.R. のローラーを裝備した精絬機數台をり、之等の機と他の 機との比較試驗を Janning 及 Kübler 式で行つたも

第1表 メイネル式とジャニング式比較

使用機 シイタ一輪具機

紡出系 20 番撚常数 $4 \cdot 18$

紡箫 1.55 番. 撚數 1.57 撚常数 1.26

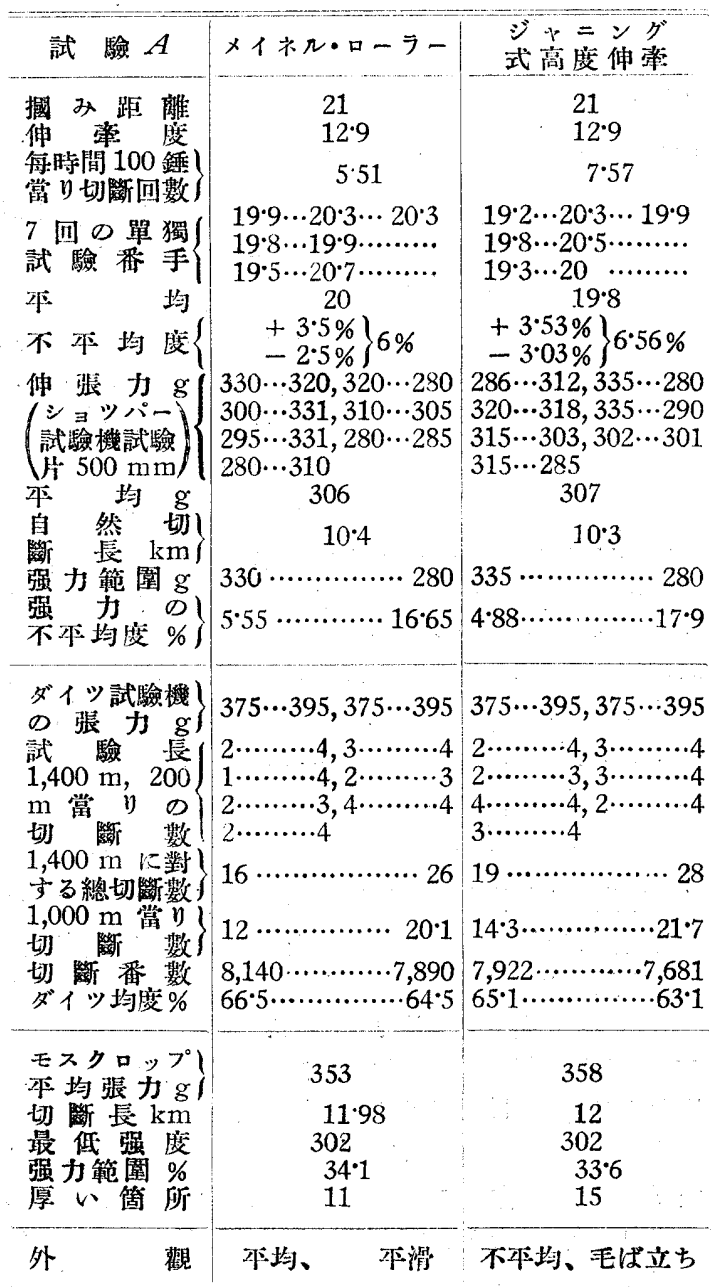

昭和 7 咋 10 月了:

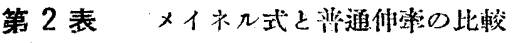

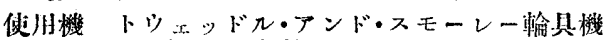
紡出系 24 番 撚常频 $4 \cdot 25$

紬 3 策 1.55 番 撚數 1.52 撚営数 1.22 メイキル・ローラーに粼しては 2.53 潘 撚数 2.53 撚常数 1.35

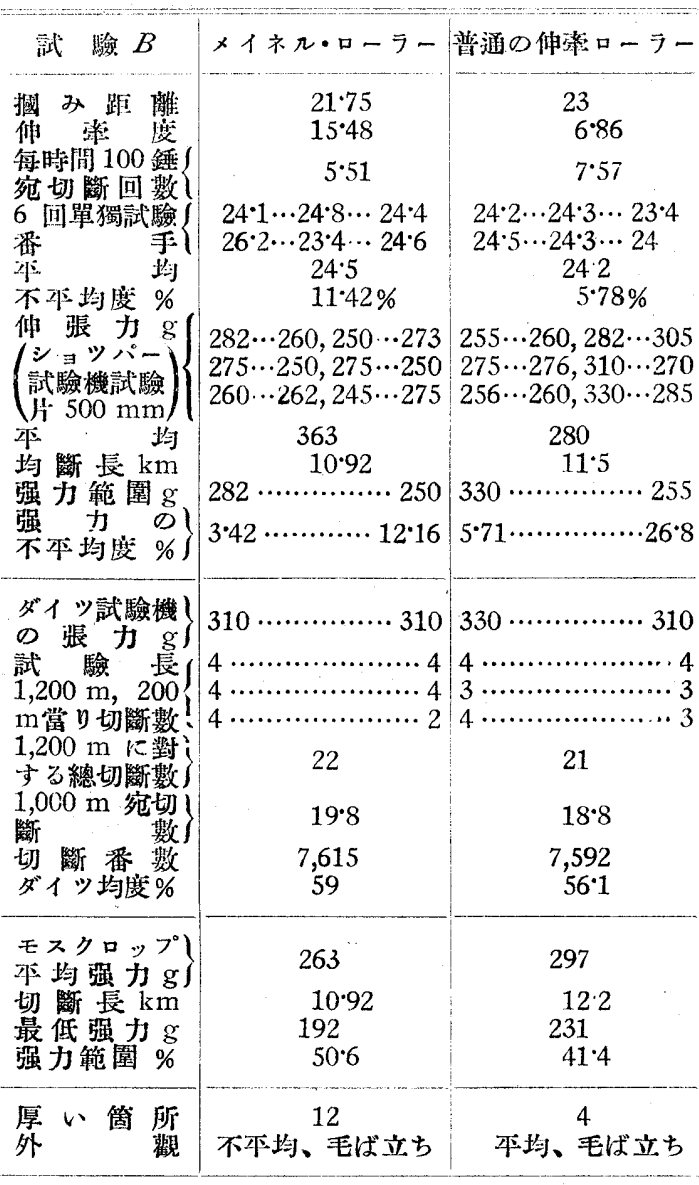

管 3 表 メイネルとキュブラー高度伂紊の比較

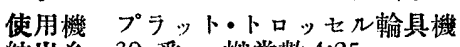

紡出系 30 番 燃常數 4.25

紡 篗 2.4 番 撚數 1.85 撚常數 1.195

\begin{tabular}{|c|c|c|c|}
\hline 試 驗 $C$ & $\frac{x 1 * n}{\text { 直徑 } 13 \mathrm{~mm}}$ & 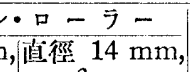 & キュブラー \\
\hline & $2 \frac{1}{2} \mathrm{oz}$ & $3 \mathrm{oz}$ & \\
\hline 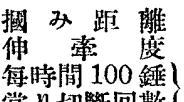 & $\begin{array}{l}20.1 \\
12.5\end{array}$ & $\begin{array}{c}20 \cdot 1 \\
12 \cdot 5 \\
-\end{array}$ & 0 \\
\hline
\end{tabular}

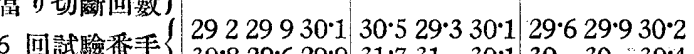

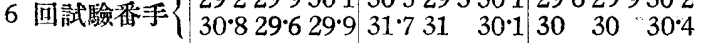
\begin{tabular}{|c|c|c|c} 
平均不均度 $\%$ & 29.9 & 30.4 & 30 \\
不 & 5.35 & 7.9 & 2.66
\end{tabular} 不本均庭 \%

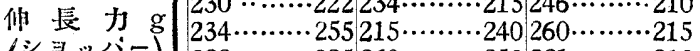

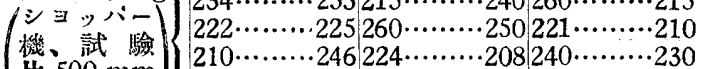

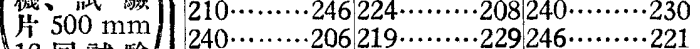

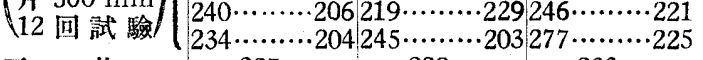
\begin{tabular}{cr|c|c|c} 
平 均 $\mathrm{g}$ & 227 & 228 & 233 \\
切 斷 長 $\mathrm{km}$ & 11.5 & 11.7 & 11.84
\end{tabular}

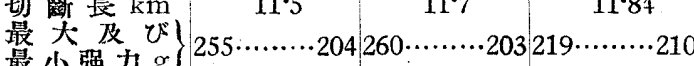

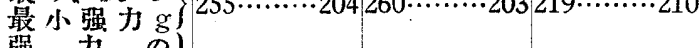

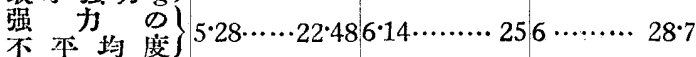

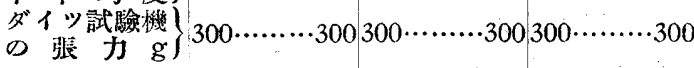

